JEASP

Journal of English for Academic and Spesific Purposes

Volume 1 Number 1, June, 2018

\title{
TEACHING PART OF SPEECH AND WORD GROUPS AS UNITS OF MEANING IN ESP SPEAKING CLASS
}

\author{
Urwatus Silvia Rahmah \\ (viasilviara13@gmail.com) \\ Pusat Pengembangan Bahasa Inggris \\ Universitas Islam Negeri Maulana Malik Ibrabim Malang
}

\section{ARTICLE \\ Keywords: ESP, \\ Part of Speech, \\ Speaking Class.}

\begin{abstract}
English for Specific Purposes (ESP) is known as a learner-centered approach to teach English as a foreign or second language. Students learn English for a specific purpose, represented by studying subject matter, to gain and develop appropriate knowledge and skills through English. They have to perform task in English, meanwhile they are also supposed to be mastered in speaking skill. The objective of this paper is to build the student's speaking ability effectively by using English. Teaching part of speech and word groups as units of meaning are used in the class. They have to know the words first and then able to classify them as basic of their speaking. The activities include in some parts, they have listening section to start the activity, then grouping the students and asking them to tell the information in front of the class. The aims of this activity are to encourage their competence in English speaking and also make them involve in speaking class. Thus, this paper aims to give a clear explanation and a deeper insight about teaching part of speech and word groups as unit of meaning, stimulate all of teachers of ESP to implement the material in their teaching processes and make them realize in choosing the appropriate material to teach their students.
\end{abstract}

\section{INTRODUCTION}

English for Specific Purposes (ESP) is known as a learner-centered approach to teach English as a foreign or second language. Students learn English for a specific purpose, represented by studying subject matter, to gain and develop appropriate knowledge and skills through English. ESP students are quite different with students whom are from English department. Some of them think that English is considered as a difficult lesson. It occurs when they learn English, especially in speaking class. They are afraid to produce some words by making mistakes because they do not know how to say. They have to perform task in English, so that is way they are also supposed to be mastered in speaking skill. Harmer (1998: 87) states that there are three basic reasons why it is a good idea to give students speaking tasks. The first one is getting the students to communicate or discus outside the classroom, allowing 
JEASP

Journal of English for Academic and Spesific Purposes Volume 1 Number 1, June, 2018

them to rehearse such a real life foreign language communication. The second one is by speaking tasks; it will provide feedback for both teacher and students. Teacher really knows how well their students ability by language problems they are having. Speaking activities can encourage the students' confidence and satisfaction while they are learning English. The last reason is that speaking activities engage the students to involve or participate fully if the activity really makes them intrinsically enjoyable. The teacher should set up the activity properly and should be highly motivated for the students.

Teaching speaking is one of skill that students should be mastered in English. Because sometime, student's English ability looked from his or her ability to communicate in English which is include their fluency and accuracy. And of course, when they want to produce some words they should have some background of knowledge for their speaking. But some of students are afraid to produce some words by making mistakes because they do not know how to say. They have to perform task in English, so that is way they are also supposed to be mastered in speaking skill. According to Harmer (1998: 87) states that there are three basic reasons why it is a good idea to give students speaking tasks. The first one is getting the students to communicate or discus outside the classroom, allowing them to rehearse such a real life foreign language communication. The second one is by speaking tasks; it will provide feedback for both teacher and students. Teacher really knows how well their students ability by language problems they are having. Speaking activities can encourage the students' confidence and satisfaction while they are learning English. The last reason is that speaking activities engage the students to involve or participate fully if the activity really makes them intrinsically enjoyable. The teacher should set up the activity properly and should be highly motivated for the students. And according to Brown (2007: 331-332) there are some principles behind the teaching of speaking. The first principle is that speaking should focus on both fluency and accuracy, depending on the objectives. Another is that speaking should provide intrinsically motivating techniques and help the students to see how the activity will benefit them. And speaking should encourage the use of authentic language in meaningful contexts by using drills can be structured to provide a sense 
JEASP

Journal of English for Academic and Spesific Purposes

Volume 1 Number 1, June, 2018

of authenticity. It also should provide appropriate feedback and correction from the teacher. In other hand, capitalize on the natural link between speaking and listening. It is such kind of integrated skills which increase their abilities in English skill. The teacher also gives students opportunities to initiate oral communication such as, the ability on conversation, ask question, and perhaps create a new topic. The last one is that encourage the development of speaking strategies by providing the concept of strategic competence for accomplishing oral communicative purposes.

Communication is one way to deliver a message to another people. So, in this case the writer emphasizes on student's speaking ability from morphology insight. This is the area of linguistic which studies the structure of words. Certainly, teaching part of speech and word groups as units of meaning are used in the class. It will build the student's speaking ability effectively by using English. They have to know the words first and then able to classify them as basic of their speaking. The teacher also must be creative to find out the way of teaching in order to make the students understand and interested in teaching learning process. And this is also a major part of the teacher's job to expose student's language so that they can use it later. Teaching part of speech to the students can improve their speaking ability, enrich their vocabulary and also help them to communicate effectively after they know the basic part of the words. The writer also wants to explain to the readers that teaching part of speech to ESP speaking class is one of good materials to be applied to the students as their basic knowledge before they get speaking practice in a class.

\section{THE TOPIC}

Words consist of more than just spelling, sounds and meanings. It also falls into grammatical categories such as nouns and verbs. Words are also what human beings use to communicate everything from basic needs to explain the messages. According to O' Grady and Dobrovolsky (1992: 115), the system of categories and rules involved in word formation and interpretation called morphology. In order to be able to talk about language, we need to know various things about the elements of the speech. In linguistic morphology, parts of speech are defined according to their syntactic function: The difference between nouns and verbs is that they cannot 
appear in the same environment in a sentence. Based on Ahmadin (2008:18), traditionally there are eight "parts of speech" as presented below.

\section{Conjunctions}

They are connectors used to join elements within sentences. There are four kinds of conjunctions, namely coordinators, correlative conjunctions, conjunctive adverbs, and subordinators. Here are the examples of all of them.

- Anni got up late and forgot to call her mother. (Coordinator)

- Both Raisa and Rizki are currently taking Art classes. (Correlative conjunction)

- He's not bad; rather, he's very kind. (Conjunctive adverbs)

- Nobody knows where he works now. (Subordinator)

\section{Nouns}

They are words or word groups that name persons, places, animals, things, and ideas. Below is the example of nouns.

- Raline has studied in Oxford University since 2015.

- He was walking on the sidewalk.

- Matt is an engineer.

- My sister has a lot of books. She puts her books in cupboard.

\section{Adjectives}

They are modifiers of nouns. The examples of adjectives can be seen below.

- Iqbal is diligent student. He is not only handsome boy but also the smart one.

- She has a black and white shoes.

- It seems great for you.

The words diligent, handsome, smart, black, white and great are adjectives. They are modifiers or describers of nouns. 


\section{Verbs}

They are action or being words.

- Iwan works very hard

- The lecturer explains about adjective clauses.

The words "works" and "explains" above are verbs, telling what the subject does.

\section{Adverbs}

They are modifiers elements other than nouns.

- Students are quite serious. They do their test seriously.

- The students compete fairly.

- The postman comes daily.

The word "quite" modifies adjective (serious), the word seriously modifies verb (do). Quite and seriously are adverbs. They are describers of elements other than nouns. While the word "fairly" modifies verb (compete), the word "daily" modifies verb (comes). They are describers of elements other than nouns.

\section{Pronouns}

They are substitutes for nouns.

- Dania is cute girl. Everybody likes her.

- You did everything right.

The words everybody, her, and everything are pronouns. They are substitutes for nouns.

\section{Prepositions}

They are relationship words. They show relationships between two things. In addition, they also show relationships between action and things.

- I will buy a bag and a book.

- He is talking to his mother. 


\section{Interjection}

They are words or phrases used as exclamations. They are elements in a sentence but not directly related to those other elements.

\section{- $\quad$ Oh! Good!}

- Wow! Did you see that?

Note: The underlined words are interjections.

The most important component of word structure is the morpheme, the smallest unit of language that carries information about the meaning or function $\left(\mathrm{O}^{\prime}\right.$ Grady \& Dobrovolsky, 1992:116). A word is the representation of idea which can be used in a sentence. Words that cannot be broken into smaller units of meaning are simple words. For example, the word train cannot be divided into smaller parts. However, complex words can be broken down into smaller units of meaning. For instance, if an 's added into noun train becomes trains, it becomes a complex word. According to Ahmadin (2008:21), there are three kinds of word groups namely, sentences, clauses and phrases. The explanations for the three of them are shown below.

\section{Sentences}

Sentences are full statements or questions, each with a subject predicate combination. The shortest full sentence is a two words group, subject and predicate, such as "the boy smiles".

\section{Clauses}

Clauses are subject - predicate combinations not used as full sentences by themselves.

- He did not go to school because he was sick.

- The teacher teaches the students although she is not very well.

\section{Phrases}

Phrases are groups that do not contain a subject predicate combination. Phrases can be divided into four groups, they are: 
a. Noun phrases

Noun phrases are nouns with their modifiers. Modifiers of nouns may be articles, demonstratives, possessives, indefinite adjectives, numerals, participles, other descriptive words (quality or characteristic, size or shape, color, other nouns, or they may be combination of such words).

- The student.

- My beautiful garden words.

- The closing ceremony.

b. Verb phrases

Verb phrases are verbs with their modifiers.

- She often makes mistakes.

- She is still working here.

c. Adjective phrases

Adjective phrases are adjectives with their modifiers.

- The water is very hot.

- This assignment is very difficult.

d. Adverb phrases

Adverb phrases are adverbs with their modifiers.

- He drives his car.

- The lecturer speaks English very fluently.

\section{TEACHING PROCEDURES}

In classroom activities, one of technique which is applied in conducting teaching learning process especially for teaching speaking through English language namely three phase technique. The technique consists of three activities; the first one is pre- teaching, the second one is whilst-teaching and the last one is post-teaching.

In pre-teaching, the activities involve introduction of the topic or perhaps begin with teacher's instruction. This phase has purposes to guide the students to know well about their lesson. It also will make the students have their background of knowledge, increase their motivation through learning process. And for the second 
phase is that whilst-teaching, actually this phase is the main point of view from teaching learning process.

In whilst-teaching students really learn and do the activity during the lesson. In this case, the activity emphasizes on student's centered beside the teacher is only as guide and mediator for the students. In addition, the speaking ability of the students is really shown in this phase. Because they will take role during the activity, the students speak more than the teacher. It also encourages them to produce language in appropriate method or technique which improves student's language competence. The last phase is that post-technique, this phase is the ending of the teaching stage. The purposes of this phase are the students will understand about the lesson. And from the result of the lesson, the students can practice based on the topic given.

In this section the author will show the activities in ESP speaking class ranging from pre-teaching to post teaching. The procedure of teaching is presented below.

\section{Pre-Teaching}

1. Giving a clear instruction what they are going to do in the class.

2. Providing a video lesson relates to "part of speech" (www.RudolphAcademy.com) or (http://www.youtube.com/watch?v $=$ cRr6ggbCLbU) and "word groups as units of meaning” (www.ikenstore.com) or (http://www.youtube.com/watch?v=FvsI VV3ICg\&feature=related).

\section{Whilst-Teaching}

1. After the students watch videos about their lesson, the students apply their understanding by practicing.

2. Divide the students into groups; one group consists of three people.

3. Give one copy of the worksheet to each group in the class.

4. Tell the students to write down information based on the picture in the column before, they listen the real story the title is "The First Well" retold by BookBox (www.BookBox.com). The teacher makes sure the students to guess the 
pictures and create the story based on their imagination. Encourage the students to be imaginative and to be cooperative.

5. When they have discussed with their partners and filled up all the columns. The students of each group share their own stories in front of the class.

6. After all groups have finished, the teacher gives instruction to the students that they will watch and listen the video of "The First Well" story, to consider their first own descriptions.

\section{Post-Teaching}

1. After the students watching and listening the story, the teacher gives the students homework based on the material before.

2. In-group work, the teacher gives worksheet consists of missing story script and they have to fill up the blank sentences with random answer key.

3. As for their individual work, the teacher asks the students to retell the story in front of the class based on their words.

\section{CONCLUSIONS}

In the activity illustrated above, students have the opportunity to study by watching video lesson about 'part of speech and word group as unit of meanings', then practicing it also. The focus of the learning is the students can apply what they get by making good sentences while they describe the pictures, especially in their speaking. The teacher also divides them into several groups. The students can then be asked to elaborate the story based on their imagination through the picture, which is used later for their individual, and group analysis.

By involving this activity, ESP students really improve their speaking ability. Certainly, the teacher also has important role by giving various methods for examples, providing a video or a picture that make students interested in learning English. It will help them in the process of teaching learning in order that the students can be more active in the class. This paper is expected to give a clear explanation and a deeper insight about teaching part of speech and word groups as unit of meaning, so that it can stimulate all of teachers of ESP to implement the 
material in their teaching processes and make them realize in choosing the appropriate material to teach their students. This paper is also expected to give contributions to the English teacher who wants to conduct a study on teaching ESP as their supporting references to develop a new study on teaching ESP.

\section{REFERENCES}

Ahmadin, D. (2008). Pre-Paragraph Writing. Malang: Penerbit Universitas Negeri Malang.

Brown, H. D. (2007). Teaching by Principles: An Interactive Approach to Language Pedagogy, Third Edition. New York: Pearson-Longman.

Harmer, J. (1998). How to Teach English: An Introduction to the Practice of English Language Teaching. London: Longman.

O'Grady, W. \& Dobrovolsky, M. (Eds.). (1992). Contemporary Linguistic Analysis: An Introduction ( ${ }^{\text {nd }}$ edition). Toronto: Copp Clark Pitman. 


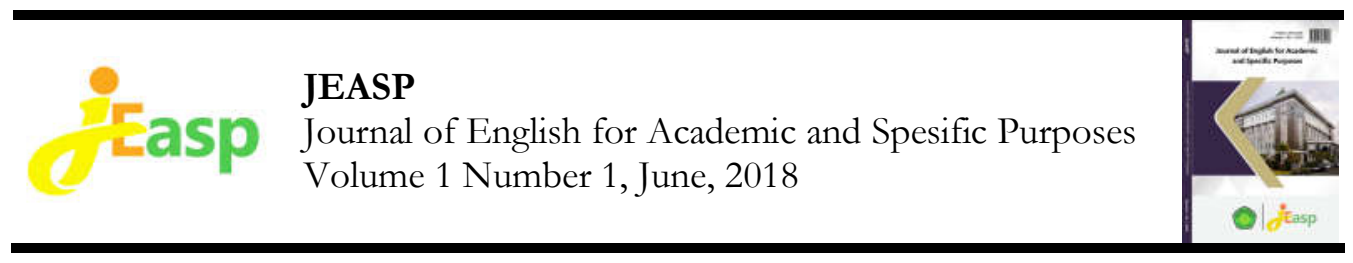

APPENDIX

\section{A. Picture Cued Elicitation Of Description}

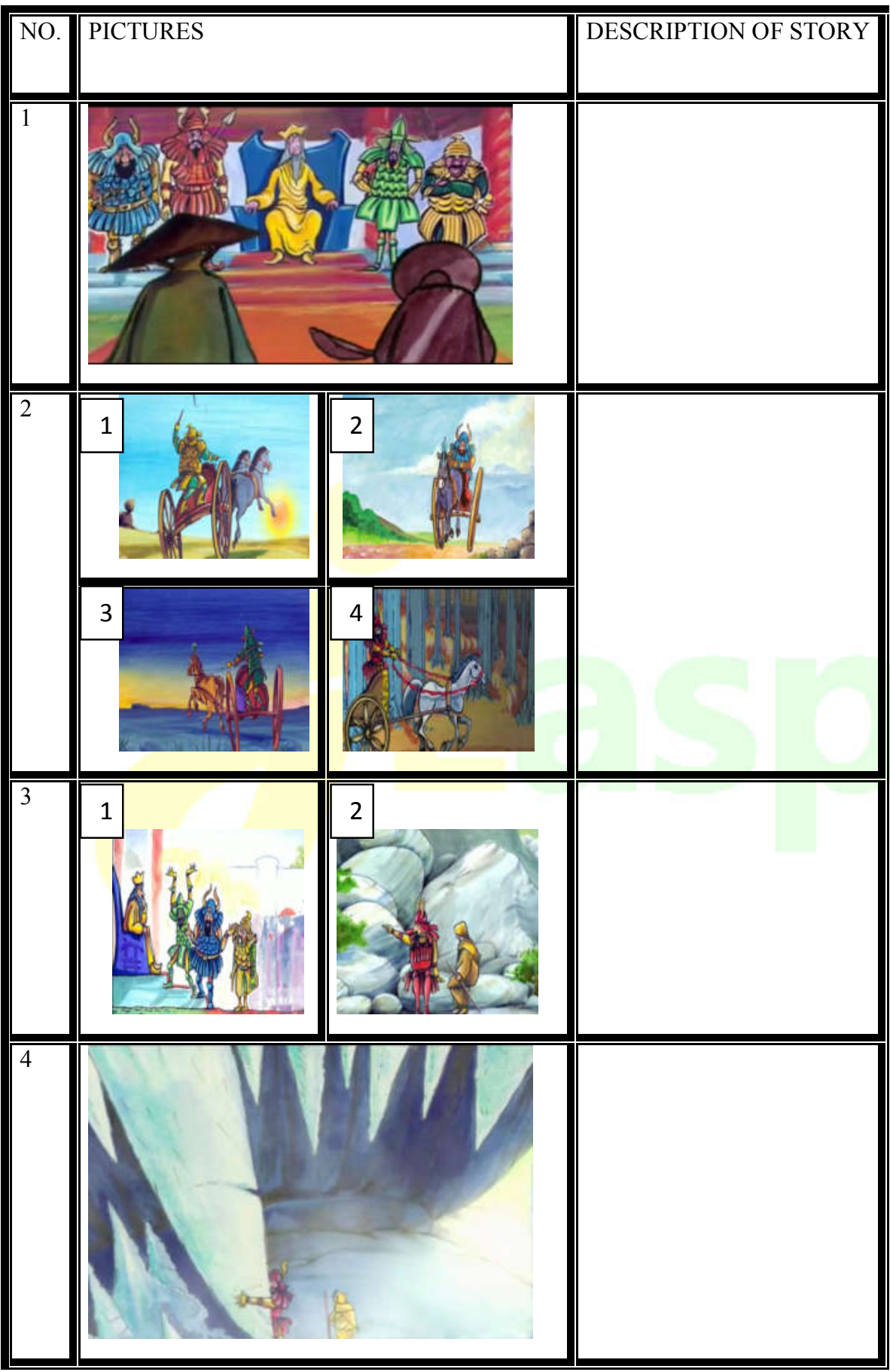



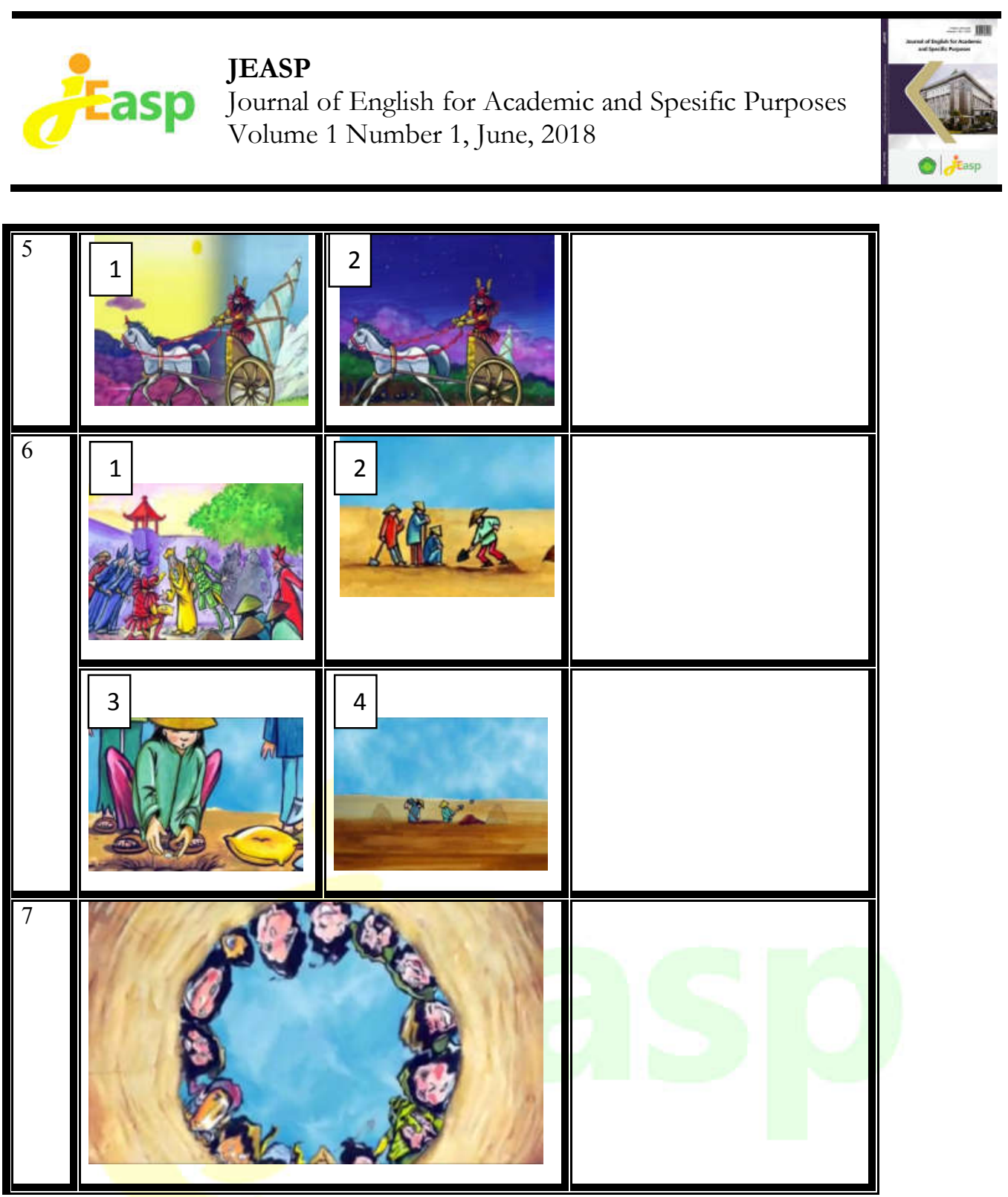

B. Homework for the Students

- Group Work

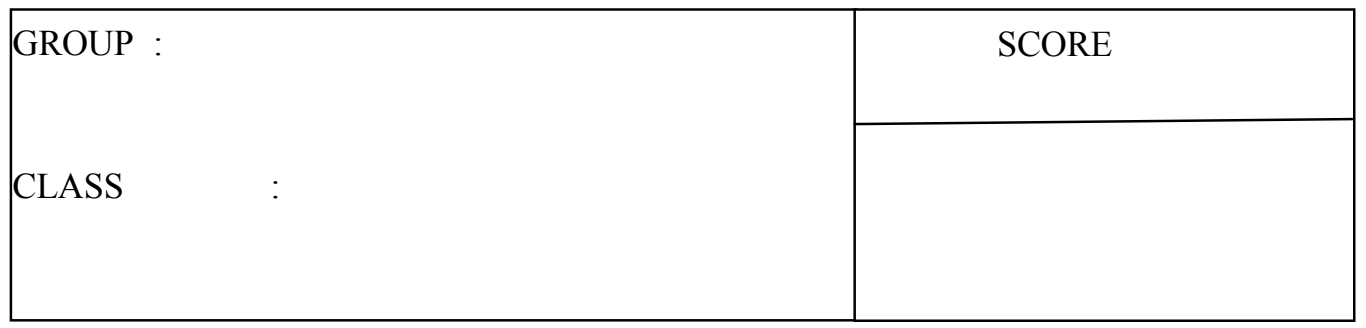

THE FIRST WELL

There once was a small kingdom around a lake. One very hot summer it did not rain and the lake dried up. People............anxious and went to the king. "It has not rained for so long. Our fields are barren!" said the farmers. "There's no fish to catch. How shall we earn a living?" asked . "Save us from. good king," urged the woman and the children cried 


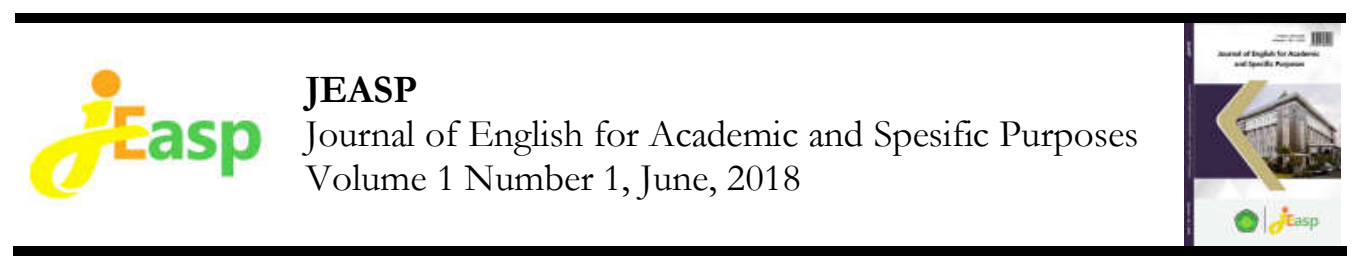

with thirst. The king sent his four to search for water in all directions. The first general went east, towards the sunrise; the second to the south, to dust and heat, the third went west, where the sun sets and the fourth followed the North Star.

They search day and night, night and day, high and low; they searched everywhere but in vain. Three of the generals returned, empty-handed. But the general who had gone north ............, not to fail his king, finally ............ a cold mountain village. As he sat, at the foot of the mountain, and ............. came by and sat next to him. The general pointed at the $\ldots \ldots \ldots \ldots \ldots \ldots$ and said, "I belong to $\ldots \ldots \ldots \ldots \ldots \ldots \ldots$, where it has not rained for a whole year. Can you help me find water?" The woman motioned the general to follow her up the mountain and inside .......... . "We have no water in our country either," she said. Then, pointing to the icicles in the cave, she continued, "We call this ice. Take some, and your kingdom will never go thirsty again." The general broke off a huge piece, loaded it onto his ............. and rushed back home.

By the time he the court, the icicle had melted into a small lump of ice. Nobody in the court had ever seen ice, so everybody gazed at it with wonder!" This must be a water-seed," one of the ............. exclaimed suddenly. The king ordered the "water-seed' to be ........... immediately. While the farmers dug a hole, the lump dwindled in the sun. They swiftly placed the seed in the hole, but, ........... they could cover it, it had vanished. The farmers there got confuse and worried. They dug the earth deeper and deeper, into the night, looking for the mysterious .......... At the break of dawn, the king found the farmers fast asleep around a hole. Curiously, he peeped in and cried out in ............... "Wake up my worthy men, the water-seed has sprouted! There's water in the hole!". This is how the first well was created.

\begin{tabular}{|lll|}
\hline grew & a cave & the fisherman \\
horse-cart & reached & enormous \\
generals & amazement & determined \\
followed & ministers & old woman \\
before & sowed & disaster \\
beautiful kingdom & seed & horizon \\
& & \\
\hline
\end{tabular}

